\title{
Embryonic hybrid cells: a powerful tool for studying pluripotency and reprogramming of the differentiated cell chromosomes
}

\author{
OLEG SEROV ${ }^{1,2}$, NATALIA MATVEEVA ${ }^{1,2}$, SERGEY KUZNETSOV ${ }^{2}$, \\ ELENA KAFTANOVSKAYA ${ }^{2}$ and JOSANE MITTMANN ${ }^{3}$ \\ ${ }^{1}$ Institute of Biophysics, Federal University of Rio de Janeiro, 21949-900 - Rio de Janeiro, Brazil \\ ${ }^{2}$ Institute of Cytology and Genetics, Novosibirsk 630090, Russia \\ ${ }^{3}$ State University of Norte Fluminense, Campos dos Goytacazes, RJ, Brazil \\ Manuscript received on August 6, 2001; accepted for publication on August 22, 2001; \\ presented by ANTONIO C. CAMPOS-DE-CARVALHO
}

\begin{abstract}
The properties of embryonic hybrid cells obtained by fusion of embryonic stem (ES) or teratocarcinoma (TC) cells with differentiated cells are reviewed. Usually, ES-somatic or TC-somatic hybrids retain pluripotent capacity at high levels quite comparable or nearly identical with those of the pluripotent partner. When cultured in vitro, ES-somatic- and TC-somatic hybrid cell clones, as a rule, lose the chromosomes derived from the somatic partner; however, in some clones the autosomes from the ES cell partner were also eliminated, i.e. the parental chromosomes segregated bilaterally in the ES-somatic cell hybrids. This opens up ways for searching correlation between the pluripotent status of the hybrid cells and chromosome segregation patterns and therefore for identifying the particular chromosomes involved in the maintenance of pluripotency. Use of selective medium allows to isolate in vitro the clones of ES-somatic hybrid cells in which "the pluripotent" chromosome can be replaced by "the somatic" counterpart carrying the selectable gene. Unlike the TCsomatic cell hybrids, the ES-somatic hybrids with a near-diploid complement of chromosomes are able to contribute to various tissues of chimeric animals after injection into the blastocoel cavity. Analysis of the chimeric animals showed that the "somatic" chromosome undergoes reprogramming during development. The prospects for the identification of the chromosomes that are involved in the maintenance of pluripotency and its cis- and trans-regulation in the hybrid cell genome are discussed.
\end{abstract}

Key words: ES cells, EG cells, hybrid cells, pluripotency, reprogramming.

\section{INTRODUCTION}

The past twenty years have seen the success of developmental biologists in culturing embryonic cells in vitro. In 1981, reports came from two laboratories that pluripotent cell lines isolated from normal mouse blastocysts have been established (Evans and Kaufman 1981, Martin 1981). Subsequently, primordial germ cell cultures have been produced (Donovan 1994). These cells were able to retain

Correspondence to: Dr. Oleg Serov

E-mail: serovol@hotmail.com many properties of pluripotent embryonic cells when kept long in conditioned medium. They were termed embryonic stem (ES) and embryonic germ (EG) cells to denote their origin. An attractive feature of the ES cells is their developmental potential, which is brought into prominence when the ES or EG cells are injected into the blastocoel cavity of early embryos (blastocysts). With this approach, embryos develop to chimeras and the ES or EG cells contribute to all the somatic tissues and to germ line (Robertson and Bradley 1986, Robertson 1987, Al- 
lan 1987, Joyner 1993, Hogan et al. 1994). Thus, ES and EG cells allowed to bridge the gap between in vitro and in vivo experimental approaches for studying early development and embryonic differentiation.

Culturing the ES and EG cells in vitro makes feasible the application of the strategy of cell hybridization widely used in cell biology. Hybrid cells produced by fusion of ES and EG cells with differentiated cells derived from adults allow to gain insight into the interaction of genomes with different "developmental histories". A unique situation is created in these hybrid cells in which homologous chromosomes originated from cells at different differentiation stages are brought together within a common nucleus where they can readily exchange regulatory trans-acting signals. It is not at all immediately apparent how the $c i s$-regulatory epigenetic systems of the homologous chromosomes established in individual development of the parental cells would respond to the trans-acting signals emitted by the contrasting parental genomes. What is also consequential is that the parental chromosomes segregate in the hybrid cells. This offers good opportunities for studying genome interactions at the level of single chromosomes, to identify the involvement of particular chromosomes in pluripotency maintenance or vice versa their entrance into differentiation.

\section{TERATOCARCINOMA-SOMATIC CELL HYBRIDS}

Hybrid cells isolated by fusion of teratocarcinoma (TC) cells with somatic cells were the early tools for investigating the interaction of genomes differing by their "developmental histories". The TC cells are similar to ES in certain features. In fact, they were observed to have high levels of pluripotency (Papaioannou and Rossant 1983). It is of interest that the hybrid cells generated by fusion of TC cells with somatic cells retain pluripotency potential. Thus, TC-somatic hybrid cells are able to give rise to true carcinomas containing derivatives of all three embryonic germ layers (Andrews and Goodfellow 1980, Atsumi et al. 1982, Rousset et al. 1983, Takagi 1983) or to form embryoid bodies in suspension culture (Takagi 1993). The presence of embryonic antigens has been also observed in teratocarcinoma intra- and interspecific hybrids (Forejt et al. 1984, Serov et al. 1990). However, this was true only in the case when the somatic parents in fusion with the TC cells were lymphocytes or thymocytes. Hybrid cells produced by fusion of TC cells with fibroblasts resembled fibroblast with respect to morphology (Rousset et al. 1979). It is noteworthy that TC-somatic hybrid cells show evidence of reprogramming of the genome derived from "the differentiated" partner. Reprogramming is manifest as reactivation of either particular genes (Miller and Ruddle 1976, 1977, Andrews and Goodfellow 1980, Artzt et al. 1980, Rousset et al. 1983) or of the inactive $\mathrm{X}$ chromosome derived from the somatic partner (McBurney and Adamson 1976, McBurney and Strutt 1980, Takagi et al. 1983, Takagi 1988, Mise et al. 1996). Thus, the data for hybrid cells of TC-somatic cell type highlight important features. These hybrid cells not infrequently retain pluripotency and exhibit evidence of reprogramming of the somatic partner cell genome. While possessing the features of pluripotent embryonic cells (for details see Papaioannou and Rossant 1983), TC cells are inferior to the ES or EG cells in developmental potential. To illustrate, when combined with embryos, TC cells rarely generate chimeras and, moreover, are incapable to contribute to germ line. This may be explained partly by the frequent appearance of abnormal karyotypes due to loss of the Y chromosome, trisomy, deletions or translocations in TC cells (Takagi et al. 1983, Rousset et al. 1983, Modlinski et al. 1990). The view emerging from these studies is that hybrid cells generated by ES or EG-somatic cell fusion are more adequate systems for studying problems of pluripotency and reprogramming of the chromosomes of differentiated cells than TCsomatic hybrid cells.

In 1995, we have began experiments to initiate cultures of intraspecific embryonic hybrid cells by fusion of mouse ES cells with splenocytes derived from an adult female (Matveeva et al. 1996). Here, the data we obtained over the years are summarized. 
Focus is on characterization of hybrid cells, analysis of parental chromosome segregation and assessment of the hybrid cell genome pluripotency.

\section{SEGREGATION OF THE PARENTAL CHROMOSOMES IN ES AND EG HYBRID CELLS}

Chromosome segregation is usually low in intraspecific hybrid cells produced by fusion of TC cells with somatic cells. These cells often have a tetraploid or near-tetraploid complement of chromosomes (Rousset et al. 1983, Takagi et al. 1983, Forejt et al. 1984, Takagi 1993, 1997, Mise et al. 1996). A similar chromosome composition has been described for hybrid cells obtained by fusion of primordial germ cells with lymphocytes (Tada et al. 1997). A consequence of cell fusion between mouse TC cells and mink lymphocytes was intense segregation of the somatic partner chromosomes in the interspecific hybrid cells only (Serov et al. 1990).

A major breakthrough in segregation studies of the parental chromosomes in intraspecific hybrids came with the development of methods for microsatellite analysis using the polymerase chain reaction (PCR). By the end of 1999, more than 6,000 polymorphic microsatellites have been described in laboratory mouse strains. This meant availability of hundreds of markers for each mouse chromosome, and this made feasible the discrimination of any pair of homologous chromosomes in hybrid cells (Website // www.informatics.jax.org Jackson Laboratory).

In our experiments, ES cells (hypoxanthine posphoribosyltransfrase, HPRT- deficient cell line HM-1, $2 n=40$, XY genotype) isolated from HPRTdeficient strain 129/Ola mice (Magin et al. 1992) were fused with splenocytes from an adult female of $\mathrm{DD} / \mathrm{c}$ mice (Serov et al. 1994). We succeeded in establishing a set of hybrid clones similar to ES cells in morphology (Matveeva et al. 1996, 1998). Hybrid cell clones were isolated in selective HAT medium, which ensures growth of only HPRT-positive cells. Electrophoretic analysis demonstrated that all the clones contained the allelic HPRT variant typical of DD/c mice (Serov et al. 1994). Four hybrid clones were examined cytogenetically; surprisingly, 3 had a near-diploid complement and 1 had a near-tetraploid complement of chromosomes.

Analysis of microsatellites allowing to discriminate any pair of 129/Ola and DD/c homologous chromosomes in hybrid clones with a near-diploid chromosome complement demonstrated distinct elimination of the somatic partner chromosomes in two clones. Most autosomes in HESS2 and HESS3 clones had only 129/Ola markers of the pluripotent parental ES cell. However, chromosomes 1 and 11 were exceptional: along with markers of ES cells, those of the somatic partner were found to be present in small amounts in the two clones (Matveeva et al. 1998, 2001). This may reflect incomplete segregation of chromosomes 1 and 11 derived from the somatic partner and is also consistent with cytogenetic data indicating that chromosomes 1 and 11 are trisomic in $30-40 \%$ of HESS2 and HESS3 cells (Matveeva et al. 1998, 2001). However, one clone with a near-diploid chromosome complement differed considerably in chromosome composition from HESS2 and HESS3. Although many HESS4 autosomes were derived from the ES cell genome, chromosomes 1, 9, 11, 12, 15, 16, 18 and 19 were represented by homologs of both parents (Matveeva et al. 2001). It should be noted that the ratio of microsatellites marking the homologous chromosomes was close to $1: 1$. This suggested that in HESS4 cells one homolog of chromosomes mentioned above was derived from the ES cell genome, the other from the differentiated cell genome. Interestingly, in some HESS4 subclones, only markers of chromosomes 18 and 19 of the somatic partner were present. The obtained results indicated that in HESS4 cells, along with segregation of the somatic partner derived chromosomes, there occurred an elimination of one or two homologs of the above listed chromosomes of the pluripotent cell genome, i.e. segregation of the parental chromosomes was bilateral. This is unusual because segregation of the chromosomes of just one partner is typical of hybrid cells.

Of particular interest was the observation that 
the hybrid cell clones after passage 20 contained only markers of the X chromosome from the somatic partner (Matveeva et al. 2001). It was inferred that the $\mathrm{X}$ chromosome from the ES cell genome was replaced by the $\mathrm{X}$ from the somatic partner. The in situ hybridization data obtained using a FITClabeled probe specific to the mouse $\mathrm{X}$ chromosome supported this inference: just one chromosome gave a positive signal (Matveeva et al. 2001). It should be noted that $2 \mathrm{Xs}$ were present in some hybrid cells at early passage (up to passage 15). Surely, "the pluripotent" X chromosome was replaced by "the somatic" counterpart due to use of selective medium conducive to elimination of the "pluripotent" $\mathrm{X}$ but not "the somatic". Thus, the approach based on the use of selective media offers a means to manipulate the chromosome composition of the hybrid cells and, in a directed manner, to select clones that carry single chromosomes from the somatic partner on the background of the ES cell genome.

\section{PLURIPOTENCY OF EMBRYONIC HYBRID CELLS AND REPROGRAMMING OF INDIVIDUAL CHROMOSOMES DERIVED FROM DIFFERENTIATED CELLS}

Residence of the parental genomes within a single nucleus is a unique feature of hybrid cells. This raised the question of whether the ES cell genome retains its pluripotency capacity when in close contact with the differentiated cell genome in the ESsomatic cell hybrids.

As indicated above, the hybrid cells with a diploid karyotype had morphology similar to that of the parental ES cells. Various in vitro and in vivo tests were used to assess the pluripotency of the hybrid cells. All the clones examined, when kept in suspension, maintained the developmental potential to form embryoid bodies containing the derivatives of all three embryonic germ layers (Matveeva et al. 1998). Most hybrid cells had antigen ECMA-7, a marker typical of early mouse embryos (Pascoe et al. 1992), and showed high activity of alkaline phosphatase. A series of experiments in which "injected" chimeras were produced with significant contribu- tion of hybrid cells validated the pluripotency capacities of hybrid cells (Matveeva et al. 1998). In fact, analysis of biochemical markers (glucose phosphate isomerase) and coat color demonstrated the presence of the descendants of donor hybrid cells in most chimeric tissues. Taken together, the data indicated that the hybrid cells produced by fusion of the ES cells and somatic differentiated cells retained pluripotency at quite high levels so that they were able to form chimeras when injected into host blastocysts.

As noted, clones with a diploid karyotype differed markedly in the composition of the parental chromosomes. Nevertheless, all clones had similar pluripotent characteristics judging by the in vitro tests. This may be taken to mean that pluripotency behaves as a dominant trait in the hybrid cell genome. However, it cannot be excluded that not all chromosomes participated in the maintenance of pluripotency. If so, elimination of some of the pluripotent partner chromosomes from the hybrid cell genome would not affect their pluripotent status. Then, segregation analysis of the parental chromosomes in the hybrid cells would bring us closer to a correct identification of the chromosomes that are involved in the control of pluripotency in hybrid cells.

None of the 50 offspring from crosses between chimeras and normal mice was of 129/Ola genotype and none carried an X of DD/c strain. We suggest two likely causes for this. One is a decrease in pluripotency of hybrid cells under the effect of the somatic genome. Another cause may by the deleterious influence of autosomal trisomy and of unbalanced sex chromosomes (some cells maintained for up to 15 passages had XXY karyotype). It will be recalled that cells of XXY genotype cannot undergo meiosis and result in gametes (Endo et al. 1991). Autosomal trisomy may reduce the proliferative activity of hybrid cells and, as a consequence, cells of the host embryo may be conferred selective advantage in the development of chimeras (Hernandez and Fisher 1999). Therefore, it appears expedient to produce clones with a normal diploid complement of 
chromosomes to adequately assess the pluripotency capacity of hybrid cells.

It is noteworthy that these experiments demonstrated for the first time that the $\mathrm{X}$ chromosome derived from the somatic cells could be reprogrammed in the hybrid cell genome. This conclusion follows from analysis of the expression of the Hprt gene, a marker of "the somatic" X-chromosome, in chimeras. The allelic HPRT variant of DD/c mice was identified in all chimeric tissues (Matveeva et al. 1998). It is also pertinent to note that, once the hybrid cells happen to be in the blastocoel cavity, they encounter non-selective conditions, and retention of the somatic $\mathrm{X}$ in the hybrid cell genome means that it becomes its obligatory component. Thus, the hybrid genome does not discriminate it from the $\mathrm{X}$ chromosome of the pluripotent partner. Evidence for reprogramming of the somatic genome in hybrid cells obtained by fusion of EG with lymphoid cells has been provided by Tada et al. (1997) who have observed demethylation at the imprinted loci derived from the somatic partner in EG-somatic cell hybrids with a tetraploid chromosome complement.

It is worthwhile to reemphasize that analysis of the pluripotent and somatic genomes interaction in hybrid cell demonstrated a dominant behavior of the pluripotency trait. More than that, the hybrid genome is able to reprogram individual chromosomes of differentiated cells. This line of reasoning does not rule out the reverse: the influence exerted by the somatic cell genome on the pluripotency of the embryonic cell genome. We observed that cell differentiation was induced much more readily in the hybrid cell cultures than in the parental ES cell line, HM-1 cells. A similar effect was observed also during the formation of primary hybrid clones: many of them differentiated at the stage of their formation and, for this reason, loss of clones was high during their selection.

\section{PROSPECTS FOR USE OF EMBRYONIC HYBRID CELLS IN STUDY OF EMBRYONIC PLURIPOTENCY}

The knowledge obtained in generating hybrid cells by fusion of ES and somatic cells demonstrated that these cells retain the unique property of the embryonic genome - pluripotency - despite its close contact with the differentiated cell genome. More than that, reprogramming of individual chromosomes derived from differentiated cells is feasible in such hybrid cells, especially, when they combine with embryos and give rise to chimeras. The challenging questions are, to what level the pluripotent capacity of the embryonic cell genome are retained by the parental ES cells and what is their contribution to the germ line in chimeras? Answers are to be sought in embryonic hybrid cells that have the normal karyotype. In any event, pluripotent embryonic hybrid cells can now become a new genetic model for identification of chromosomes involved in the maintenance and control of pluripotency. The revealed bilateral segregation of the parental chromosomes would be of benefit to development of such genetic models.

Studies of the phenomenon designated "chromosome memory" appear to be not less rewarding. In the hybrid cell genome, the homologous parental chromosomes are in one of two configurations: differentiation is brought to completion in the homologs from the somatic partner, while those from the pluripotent partner start to differentiate. Retention of the high pluripotent capacity by the hybrid cells shows that the pluripotent configuration of the ES cell homologs in the hybrid genome is quite stable notwithstanding the transacting effects exerted by the somatic partner. True, the homologous chromosomes of the differentiated genome show signs of reprogramming. However, this does not exclude that, at the early steps of formation and in vitro culturing of the hybrid cells, the homologs derived from the somatic partner retain also the status they have acquired during cell differentiation in the developing animal, donor of somatic cells. Judging by our more recent observations, when embryonic hybrid cells (before 10-15 passages) are placed in vitro in non-selective conditions, the chromosomes of only the somatic partner are strongly eliminated and, as a result, the chromosome complement identical with that of the ES 
cell partner is restored in hybrid cells. This implies easy discrimination of the parental homologs by the hybrid cell genome in in vitro culture. This may be interpreted that the "somatic" homologs have not become equivalents of their "pluripotent" counterparts in the hybrid cell genome, and, therefore, they are incompletely reprogrammed. Given all these considerations, embryonic hybrid cells will surely be of benefit in experimental approaches to studies of the basic properties of the embryonic cell genome pluripotency and its alternative embryonic differentiation.

\section{ACKNOWLEDGEMENTS}

This work was supported by grants from the CNPq/PADCT, FAPERJ, FUJB, the Russian Fund of Basic Research (01-04-49516), the Fund Russian University for Fundamental Research $(1772 / 3 \mathrm{H}-$ 320-98) and Russian Fund Newest Methods in Bioengineering and Cell Biology (05.01.04.53).

\section{RESUMO}

As propriedades de células embrionárias híbridas obtidas pela fusão de células tronco embrionárias (ES) or células de teratocarcinoma (TC) com células diferenciadas são revistas. Usualmente, híbridas ES-célula somática ou TC-célula somática retêm a capacidade de pluripotência em altos níveis, bem comparáveis ou virtualmente idênticas à capacidade da parceira pluripotente. Quando cultivadas in vitro, clones celulares híbridos dos tipos EScélula somática e TC- célula somática, via de regra, perdem os cromossomos derivados da parceira somática. Entretanto, em alguns clones os autossomos da parceira ES são também eliminados, i.e., os cromossomos paternos se segregam bilateralmente nas híbridas ES-célula somática. Isto abre vias para a busca de correlações entre o status pluripotente das células híbridas e padrões de segregação cromossômica e, conseqüentemente, para a identificação dos cromossomos envolvidos na manutenção da pluripotencialidade. $\mathrm{O}$ uso de meios seletivos permite isolar in vitro os clones os clones de células híbridas ES-célula somática no qual o cromossomo "pluripotente" pode ser substituído por sua contrapartida "somática" que carreia o gene selecionável. Diferentemente da híbrida TC-célula somática, as híbridas ES-célula somática com conteúdo quasi-diplóide de cromossomos são capazes de contribuir para vários tecidos de animais quiméricos após injeção na cavidade blastocélica. A análise de animais quiméricos mostrou que os cromossomos somáticos sofrem reprogramação durante o desenvolvimento. As perspectivas para a identificação de cromossomos que estão envolvidos na manutenção da pluripotencialidade e na sua cis- e transregulação no gnoma da célula híbrida são discutidas.

Palavras-chave: Células-tronco embrionárias (ES), células germinais (EG), células híbridas, pluripotencialidade, reprogramação.

\section{REFERENCES}

Allan B. 1987. Production and analysis of chimeric mice. In ROBERTSON RJ, editor. Teratocarcinoma and Embryonic Stem Cells. A Practical Approach. Oxford: IRL Press Limited, pp. 125-139.

Andrews PW And Goodfellow PN. 1980. Antigen expression by somatic cell hybrids of a murine embryonal carcinoma cell with thymocytes and L cells. Somat Cell Genet 6: 271-284.

Artzt K, Jacobs-Cohen RJ, Dimeo A, Alton AK and DARLING G. 1980. Reexpression of a T/t-complex antigen $\left(\mathrm{t}^{12}\right)$ in thymocyte $\mathrm{x}$ embryonal carcinoma cell hybrids. Somat Cell Genet 7: 423-434.

Atsumi T, Shirayoshi Y, TAKeichi M AND OKada TS. 1982. Nullipotent teratocarcinoma cells acquire the pluripotency for differentiation by fusion with somatic cells. Differentiation 23: 83-86.

Donovan P. 1994. Growth factor regulation of mouse primordial germ cell development. Curr Top Dev Biol 229: 189-225.

Endo A, Watanabe T and Fujita T. 1991. An XXY sex chromosome anomaly in the mouse. Genome 34 : 41-43.

Evans MG AND Kaufman MH. 1981. Establishment in culture of pluripotent cells from mouse embryos. Nature 292: 154-156.

Forejt J, Gregorova S, Dohnal K and NoseK J. 1984. Gene expression of differentiated parent in teratocarcinoma cell hybrids. Repression or reprogramming? Cell Diff 15: 229-234. 
Hernandez D And Fisher EMC. 1999. Mouse autosomal trisomy: two's company, three's a crowd. Trends in Genetics 15: 241-247.

Hogan B, Beddington R, Constantini F and Lacy E. 1994. Manipulating the Mouse Embryo. 2. ed. New York: Cold Spring Harbor Laboratory Press, p. 497.

Joyner AL. 1993. Gene Targeting. A Practical Approach. Oxford: Oxford University Press, p.234.

Magin TM, McWhir J And Melton DW. 1992. A new mouse embryonic stem cell line with good germ line contribution and gene targeting frequency. Nucleic Acid Res 20: 3795-3796.

MARTIN GR. 1981. Isolation of a pluripotent cell line from mouse embryos cultured in medium conditioned to teratocarcinoma stem cells. Proc Natl Acad Sci USA 78: 7634-7638.

Matveeva NM, Shilov XG, Bayborodin Si, PhilimoNENKo VV, Rolinskaya IV AND SEROV OL. 1996. Hybrid between mouse embryonic stem and somatic cells retain pluripotency. Proc Acad Sci Russia 349: 129-132.

Matveeva NM, Shilov AG, Kaftanovskaya HM, Bayborodin SI, Fokina MM, Maximovsky LP, Zhelezova AI, Golubitsa AN and Serov OL. 1998. In vitro and in vivo study of pluripotency in hybrid cells obtained by fusion of mouse embryonic stem cells with splenocytes. Mol Reprod Dev 50: 128-138.

Matveeva NM, Kuznetsov SB, Kaftanovskaya EX AND SERov OL. 2001. Segregation of the parental chromosomes in hybrid cells obtained by fusion between embryonic stem cells and differentiated cells derived from an adult. Proc Acad Sci Russia 379: 650-653.

McBurney MW and Adamson ED. 1976. Studies on the activity of the $\mathrm{X}$ chromosomes in female teratocarcinoma cells in culture. Cell 9: 57-70.

McBurney MW and Strutt BJ. 1980. Genetic activity of $\mathrm{X}$ chromosomes in pluripotent female teratocarcinoma cells and their differentiated progeny. Cell 21: 357-364.

Miller RA ANd Ruddle FH. 1976. Pluripotent teratocarcinoma-thymus somatic cell hybrids. Cell 9: 45-55.
Miller RA And Ruddle FH. 1977. Properties of teratocarcinoma-thymus somatic cell hybrids. Somat Cell Genet 3: 247-261.

Mise N, Sado T, Tada S and Takagi N. 1996. Activation of the inactive $\mathrm{X}$ chromosome induced by cell fusion between a murine EC and female somatic cell accompanies reproducible changes in the methylation pattern of the Xist gene. Exp Cell Res 223: 193-202.

Modlinski JA, Gerhauser D, Lioli B, Winking H AND ILLMENSEE K. 1990. Nuclear transfer from teratocarcinoma cells into mouse oocytes and eggs. Development 108: 337-348.

Papaionnnou VE and Rossant J. 1983. Effects of the embryonic environment on proliferation and differentiation of embryonal carcinoma cells. Cancer Surveys 2: 165-183.

Pascoe WS, Kemler R and Wood SA. 1992. Genes and functions: trapping and targeting in embryonic stem cells. Biochem Biophys Acta 1114: 209-221.

Robertson EJ. 1987. Embryo-derived stem cell lines. In: RoberTson EJ, editor. Teratocarcinomas and Embryonic Stem Cells. A Practical Approach. Oxford: IRL Press Limited, pp 71-112.

Robertson E and Bradley A. 1986. Production of permanent cell lines from early embryos and their use in studying developmental problems. In: J RosSANT AND RA PEDERSEn (eds). Experimental Approaches to Mammalian Embryonic Development. Cambridge: Cambridge University Press, pp 475-508.

Rousset J-P, Dubois P, Lasserre C, Aviles D, FelLOUS M AND JAMI J. 1979. Phenotype and surface antigenes of mouse teratocarcinoma $\mathrm{x}$ fibroblast cell hybrids. Somat Cell Genet 5: 739-752.

Rousset J-P, Bucchini D AND Jami J. 1983. Hybrids between F9 nulli-potent teratocarcinoma and thymus cells produce multi-differentiated tumors in mice. Dev Biol 96: 331-336.

Serov OL, Zhdanova NS, Pack SD, Lavrentieva MV, Shilov AG, Rivkin MI, Matyakhina LD, Draber P, Kerkis AY, RogozIN IB AND Borodin PM. 1990. The mink $X$ chromosome: organization and inactivation. In: Ogita Z and C.Markert (eds). Isozymes: Structure, Function, and Use in Biology and Medicine. Progress in Clinical and Biological Research. v.344, New York: Willey -Liss, pp 589-619.

Serov OL, Golubitsa AN, Zhelezova AI and Khle- 
BODAROVA TM. 1994. Isozyme as markers for spatial organization of translation process for allelic $\mathrm{mR}$ NAs. In: Markert C, Scandalios JG, Lim H and Serov OL (eds). Isozymes: Organization and Roles in Evolution, Genetics and Physiology. New Jersey: World Scientific Publishing Inc., pp 13-21.

Tada M, Tada T, Lefebvre L, Barton SC and Surani MA. 1997. Embryonic germ cells induce epigenetic reprogramming of somatic nucleus in hybrid cells. EMBO J 3: 6510-6520.

TAKAGI N. 1988. Requirement of mitoses for the reversal of X-inactivation in cell hybrids between murine embryonal carcinoma and normal thymocytes. Expl Cell Res 175: 363-375.
TAKAGI N. 1993. Variable X chromosome inactivation patterns in near-tetraploid murine EC x somatic cell hybrid cells differentiated in vitro. Genetica 88: 107117.

TAKagi N. 1997. Mouse embryonal carcinoma cellsomatic cell hybrids as experimental tools for the study of cell differentiation and $\mathrm{X}$ chromosome activity. Cancer Genet Cytogenet 93: 48-55.

Takagi N, Yoshida MA, Sugawara O and Sasaki M. 1983. Reversal of $X$ inactivation in female mouse somatic cells hybridized with murine teratocarcinoma stem cells in vitro. Cell 34: 1053-1062.

Web-SITE wWw.informatics.jax.org Jackson Laboratory, Bar Harbor, USA. 